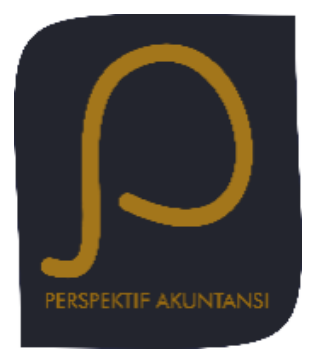

Perspektif Akuntansi

Volume 2 Nomor 2 (Juni 2019), hal. 109-119

ISSN: 2623-0194 (Print), 2623-0186 (Online) Copyright@ The Authors(s). All Rights Reserved

Fakultas Ekonomika dan Bisnis,

Universitas Kristen Satya Wacana

DOI: https://doi.org/10.24246/persi.v1i2.p109-119

http://ejournal.uksw.edu/persi

\title{
Pilihan Auditor pada Perusahaan dengan Koneksi Politik
}

\author{
Mitha Dwi Restuti 1 \\ Fakultas Ekonomika dan Bisnis, Universitas Kristen Satya Wacana
}

Received

28 September

2018

Abstract. This study examines whether companies with political connections have a tendency to choose auditors. Politically connected companies choose non-Big 4 auditors because they tend to cover rentseeking or tunneling activities and choose non-Big 4 auditors because

Accepted 24 Juni 2019 of loose supervision. Political connection criteria in accordance with Faccio (2006). Political connections are measured by the percentage of board of directors and board of commissioners who have political connections to the total members of the board of directors and board of commissioners. The test used logistic regression. The results showed that companies with political connections tended to choose non-Big 4 auditors because auditors tended to be loose in supervision. Therefore, they did not detect any rent-seeking and tunneling behavior carried out by the company.

Keywords: Political connection, auditor choice.

Abstrak. Penelitian ini menguji apakah perusahaan dengan koneksi politik memiliki kecenderungan memilih auditor. Perusahaan dengan koneksi politik memilih auditor non-Big 4 karena cenderung menutupi aktivitas rent-seeking atau tunneling dan memilih auditor non-Big 4 karena pengawasan yang longgar. Kriteria koneksi politik sesuai dengan Faccio (2006). Koneksi politik diukur dengan presentase anggota board of director dan board of comissioner yang memiliki koneksi politik terhadap total anggota board of director dan board of comissioner. Pengujian menggunakan regresi logistik. Hasil penelitian menunjukkan bahwa perusahaan dengan koneksi politik cenderung memilih auditor non-Big 4 karena auditor cenderung longgar dalam pengawasan. Dengan demikian mereka kurang

${ }^{1}$ mitha.restuti@staff.uksw.edu 
mendeteksi adanya perilaku rent-seeking dan tunneling yang dilakukan oleh perusahaan

Kata kunci: Koneksi politik, pilihan auditor.

\section{Pendahuluan}

Koneksi politik merupakan fenomena yang terjadi tidak hanya di negara maju tetapi juga di negara berkembang dan negara transisi $(\mathrm{Wu}, \mathrm{Wu}, \mathrm{Zhou}, \& \mathrm{Wu}$, 2012) termasuk terjadi di negara-negara di Asia dan juga di Indonesia. Koneksi politik terjadi karena karakteristik negara di Asia adalah negara yang struktur kepemilikannya terkonsentrasi, rendahnya penegakan hukum dan pengawasan publik, rendahnya perlindungan terhadap pemegang saham minoritas yang menyebabkan koneksi politisi menjadi pertimbangan bagi perusahaan supaya bisnis bisa berjalan dengan lancar (Claessens, Djankov, Fan, \& Lang, 2002; Haw, Hu, Hwang, \& Wu, 2004; Klapper \& Love, 2004).

Di Indonesia, koneksi politik memainkan peranan yang penting dalam menentukan nilai perusahaan (Habib, Muhammadi, \& Jiang, 2017b). Keuntungan yang bisa didapat dari adanya koneksi politik adalah adanya perlindungan dari ketidakpastian dalam menjalankan bisnis, kemudahan mendapatkan alokasi modal oleh pemerintah, pemberian dana talangan (bailouts) dan peluang bisnis yang lain (Boubakri, Guedhami, Mishra, \& Saffar, 2012; Dinc, 2005; Faccio, 2006). Dengan adanya koneksi politik tersebut perusahaan perlu menjaga koneksi dengan memiliki kinerja yang baik. Kinerja yang baik dicerminkan dengan laba yang tinggi, tetapi laba yang tinggi juga perlu dilihat apakah laba tersebut merupakan hasil adanya manajemen laba atau tidak. Perusahaan dengan koneksi politik juga dikaitkan dengan adanya manajemen laba melalui tunneling (Habib et al., 2017b). Dengan adanya manajemen laba ini menyebabkan kualitas laba menjadi buruk.

Keberadaan koneksi politik pada perusahaan menekankan bahwa ada pihak di dalam perusahaan yang bisa mempengaruhi pelaporan keuangan dengan melakukan eksploitasi sumber daya perusahaan dan mengabaikan investor. Atau bisa dikatakan bahwa adanya koneksi politik di dalam perusahaan dapat melakukan manupilasi laporan keuangan dengan tujuan menyembunyikan informasi kinerja ekonomi untuk meyakinkan bahwa tindakan mengalihkan perhatian yang berasal dari kroni politik dan korupsi tidak terungkap (Guedhami, Pittman, \& Saffar, 2014). Hal ini akan mempengaruhi kualitas laba yang dihasilkan oleh perusahaan dengan koneksi politik.

Terdapat dua pandangan mengenai kualitas laba terkait dengan perusahaan dengan koneksi politik. Yang pertama adalah perusahaan dengan koneksi politik dikaitkan dengan kualitas laba yang buruk. Penelitian Chaney, Faccio, 
dan Parsley (2011) membuktikan bahwa perusahaan dengan koneksi politik memiliki kualitas laba yang lebih buruk dibandingkan dengan perusahaan tanpa koneksi politik. Pandangan yang kedua adalah perusahaan dengan koneksi politik merupakan subyek pengawasan yang ketat, termasuk dari media dan masyarakat sehingga dikaitkan dengan kualitas laba yang lebih baik (Chaney et al., 2011).

Adanya tekanan untuk memberikan pengungkapan yang baik dan juga pelaporan keuangan dengan kualitas yang tinggi juga akan meningkatkan kualitas laba perusahaan dengan koneksi politik, terlebih apabila perusahaan memiliki tujuan bahwa investor di luar perusahaan mengetahui dan mempertimbangkan hal ini (Guedhami et al., 2014). Hal ini akan diikuti dengan pemilihan auditor oleh perusahaan, bahwa perusahaan dengan koneksi politik akan lebih memilih auditor Big 4 karena investor akan menilai transparansi perusahaan untuk kepentingan mereka. Hal ini juga memperlihatkan bahwa laporan keuangan dengan kualitas yang baik akan membantu mencegah ekspropriasi oleh pihak internal yang dominan dan kepentingan politiknya. Tetapi sebaliknya, apabila perusahaan dengan koneksi politik lebih cenderung menyembunyikan kepentingan internal, maka perusahaan akan memilih auditor non-Big 4 dengan anggapan bahwa auditor tidak terlalu ketat dalam pemeriksaan.

Perusahaan dengan koneksi politik bisa memilih auditor dengan kualitas tinggi karena perusahaan memberikan sinyal kepada pihak luar perusahaan bahwa perusahaan transparan. Di sisi lain, perusahaan dengan koneksi politik juga bisa memilih auditor dengan kualitas yang lebih rendah untuk menutupi kecurangan yang dilakukan perusahaan karena auditor cenderung longgar dalam pengawasan. Penelitian ini akan menguji apakah perusahaan dengan koneksi politik akan lebih cenderung memilih auditor yang kualitasnya lebih rendah karena perusahaan akan memanfaatkan koneksi politik dalam menjalankan bisnisnya dan menutupi kecurangan yang dilakukan dari pengawasan publik. Penelitian ini dilakukan di Indonesia karena sejak era reformasi banyak pengusaha mulai masuk ke politik dengan menjadi anggota parlemen, dalam hal ini, konteks ini menjadi menarik untuk diteliti.

\section{Pengembangan Hipotesis}

Faccio (2006) menyatakan bahwa perusahaan dapat dikatakan memiliki koneksi politik apabila setidaknya ada satu pemegang saham yang memiliki sedikitnya sepuluh persen hak suara atau manajemen puncak (board of director) menjadi anggota parlemen, menteri atau berhubungan erat dengan politisi atau partai politik. Ada beberapa hal yang menyebabkan perusahaan memiliki koneksi politik (Habib et al., 2017b) yaitu yang pertama ketika pasar 
tidak berjalan dengan baik dalam mendukung bisnis dalam hal regulasi yang berlebihan, beban pajak dan rendahnya perlindungan terhadap hak properti, maka pengusaha bergantung kepada koneksi politik untuk mengurangi hal tersebut.

Kedua, perusahaan cenderung membangun koneksi politik karena pemerintah memiliki kontrol terhadap sumber daya yang substansial dan pemerintah mempunyai kekuasaan dan diskresi untuk mengalokasikan sumber daya tersebut dan menyetujui proyek yang dibiayai pemerintah. Ketiga, teori ketergantungan sumber daya menunjukkan bahwa koneksi politik membantu perusahaan dalam memperoleh sumber daya kunci dan berurusan dengan sumber daya eksternal. Karena adanya keuntungan tersebut, perusahaan akan menjalin hubungan dengan pihak yang memiliki koneksi politik dengan tujuan kelancaran bisnis ataupun bisa mendapatkan kontrak dan bantuan dari pemerintah.

Koneksi politik di Indonesia dapat dijelaskan sejak Indonesia memasuki era reformasi setelah berakhirnya kekuasaan Suharto pada tahun 1998. Pada masa inilah perubahan terjadi pada profil sosial politik partai di Indonesia (Habib et al., 2017b). Pada masa ini banyak pelaku bisnis yang mulai masuk ke ranah politik dan mengambil alih kekuasaan yang sebelumnya dipegang oleh kalangan birokrat. Pada periode 2004-2009 terdapat banyak pengusaha memasuki parlemen. Parlemen dalam era reformasi memiliki kekuasaan yang cukup besar dalam proses legislasi dan memiliki hak untuk menyetujui birokrat dan kepala tentara dan polisi, termasuk memiliki hak untuk menentukan anggaran negara (Habib et al., 2017b).

Peranan yang baru dalam parlemen ini membawa banyak konsekuensi. Parlemen yang baru ini cenderung lebih mengadopsi pembuatan keputusan berdasarkan konsensus dibandingkan dengan menggunakan majority vote, hal ini menyebabkan elit politik bisa berperan sebagai agen rent-seeking. Sebagai tambahan, anggota parlemen, dengan kekuasaan yang signifikan juga berperan sebagai broker yang menyediakan bantuan kepada perusahaan bisnis yang ingin memenangkan kontrak dari pemerintah (Fukuoka, 2013). Koneksi politik di Indonesia menyebabkan munculnya distribusi sumber daya yang tidak seimbang dan kemudian menguatkan ketergantungan politisi pada korporasi bisnis. Korporasi bisnis kemudian mengharapkan partai politik memberi mereka kontrak dengan pemerintah atau memberikan kebijakan yang memberikan keuntungan. Hal ini dilakukan dengan menempatkan anggota parlemen di dewan komisaris atau dewan direksi perusahaan dan membentuk rezim koneksi politik. 
DeAngelo (1981) mendefinisikan kualitas audit sebagai gabungan akan dua hal yaitu auditor akan mendeteksi dan melaporkan salah saji dalam laporan keuangan dan berpendapat bahwa perusahaan audit yang lebih besar akan memiliki potensi menyediakan layanan kualitas audit yang lebih baik karena dapat berinvestasi pada teknologi audit yang lebih baik dan mempekerjakan auditor dengan keahlian yang lebih baik. Kualitas audit sering diukur dengan membedakan auditor Big 4 dan non-Big 4, hal ini disebabkan karena auditor yang ada di dalam kelompok Big 4 dianggap menyediakan kualitas audit yang lebih baik dibandingkan non-Big 4. Kualitas yang lebih baik pada auditor Big 4 ini adalah karena mereka melaporkan adanya salah saji material yang ditemukan selama proses audit, independen dan tidak terpengaruh tekanan klien. Auditor Big 4 dalam pandangan pihak di dalam perusahaan seperti pedang bermata dua, akan berdampak negatif ketika pemilik atau manajer ingin memperoleh keuntungan pribadi dan berdampak positif ketika manajer menginternalisasi kepentingan investor luar (Guedhami et al., 2014).

Audit memiliki peran penting dalam pengawasan eksternal bagi perusahaan. Dengan kualitas audit yang baik, maka pengawasan akan menjadi lebih ketat terhadap perusahaan karena kualitas audit akan menjalankan prosedur yang lebih banyak apabila menemukan risiko yang lebih tinggi. Dalam hubungannya dengan teori keagenan, adanya auditor berkualitas akan memberikan pengawasan eksternal yang lebih tinggi terhadap perusahaan sehingga asimetri informasi dapat diminimalkan dan konflik keagenan dikurangi. Penelitian Fan dan Wong (2005) menyatakan bahwa auditor eksternal dapat bekerja sebagai pengawas eksternal dan memitigasi masalah agensi pada pasar yang sedang berkembang.

Peranan auditor dalam perusahaan dengan koneksi politik berada dalam dua pandangan, yang pertama adalah bahwa perusahaan dengan koneksi politik akan memilih auditor Big 4 karena perusahaan memberikan sinyal kepada pihak di luar perusahaan bahwa perusahaan transparan. Keuntungan lain adalah nilai perusahaan yang meningkat, manajemen laba yang lebih rendah dan biaya modal yang lebih murah (Guedhami et al., 2014). Pandangan yang kedua adalah perusahaan dengan koneksi politik memilih auditor non-Big 4 karena perusahaan cenderung memberikan laporan keuangan yang buram (opaque) karena menyembunyikan adanya aktivitas rent-seeking ataupun tunneling yang cenderung dilakukan oleh perusahaan (Habib, Muhammadi, \& Jiang, 2017a).

Kondisi di Indonesia, adanya koneksi politik di perusahaan bisa jadi merupakan cara perusahaan untuk mendapatkan sumber daya dari pemerintah. Adanya koneksi politik juga mengamankan perusahaan karena masih lemahnya proteksi investor. Akan tetapi, dengan kondisi di Indonesia yang mayoritas 
kepemilikan adalah kepemilikan keluarga, memungkinkan kegiatan tunneling dan rent-seeking lebih mudah dilakukan. Guedhami et al., (2014) dan Habib et al., (2017a) mengemukakan beberapa alasan perusahaan di Indonesia mendapatkan keuntungan dengan memilih auditor non-Big 4.

Alasan tersebut, pertama, perusahaan dengan koneksi politik cenderung membuat laporan keuangan menjadi kabur untuk menyembunyikan aktivitas tunneling maupun rent-seeking mereka. Alasan kedua, ketika perusahaan meningkatkan transparansi akan berakibat menurunnya kemampuan pemegang saham pengendali dan aliansi politiknya untuk mengambil keuntungan dari kekuasaannya. Alasan ketiga adalah kurangnya transparansi dari audit non-Big 4 tidak mengurangi kesempatan untuk mendapatkan kredit dengan mudah dari bank BUMN karena memiliki koneksi politik. Selain itu biaya untuk mempekerjakan auditor Big 4 lebih mahal dibandingkan dengan auditor non-Big 4. Penelitian ini menduga bahwa perusahaan dengan koneksi politik di Indonesia akan lebih memilih auditor non-Big 4.

$\mathrm{H}_{1}$ : Perusahaan dengan koneksi politik cenderung memilih auditor non-Big 4.

\section{Metoda}

\section{Sampel}

Sampel penelitian adalah perusahaan yang terdaftar pada Bursa Efek Indonesia pada periode 2013-2016 kecuali perusahaan keuangan. Perusahaan keuangan dikeluarkan dari sampel karena perbedaan pengukuran rasio di variabel kontrol. Data awal didapat sebanyak 1.930 observasi, 730 observasi data tidak lengkap, menyisakan 1.230 observasi yang bisa digunakan. Data keuangan didapatkan dari database Thompson Reuters. Data auditor dan koneksi politik hand collected. Nama board of director dan board of commissioner diperoleh dari Bursa Efek Indonesia (http://www.idx.co.id/indeks-En.html), website perusahaan, laporan keuangan auditan dan laporan tahunan.

Data nama anggota parlemen didapatkan dari website Dewan Perwakilan Rakyat (http://www.dpr.go.id/id/anggota/), nama anggota kabinet diperoleh dari sekretariat kabinet Republik Indonesia (http://set-kab.go.id/en/profilkabinet.html). Kemudian untuk data nama gubernur diperoleh dari (http://www.kemendagri.go.id/staff-directory/gubernur-dan-wakilgubernur). Untuk data nama board of director and board of comissioner dicocokkan dengan nama anggota parlemen, nama anggota kabinet, nama kepala daerah anggota partai politik dan memiliki hubungan dekat (ayah, ibu, anak, suami, istri) dan kemudian ditentukan apakah ada koneksi politik atau tidak. 


\section{Pengukuran Variabel}

\section{Koneksi Politik}

Koneksi politik diukur menggunakan persentase jumlah board of director (BOD) atau board of comissioner (BOC) yang memiliki koneksi politik dibandingkan dengan jumlah total BOD dan BOC yang ada dalam perusahaan. Kriteria koneksi politik mengadopsi dengan (Faccio, 2006) perusahaan dengan koneksi politis adalah perusahaan yang minimal salah satu board of director dan board of comissioner menjabat sebagai anggota parlemen, menteri atau berhubungan erat (ayah, ibu, anak, kakak, adik) dengan politisi ternama atau aktif di partai politik atau merupakan anggota atau mantan militer pada periode waktu 2014-2016.

\section{Kualitas Audit}

Kualitas audit diukur menggunakan variabel dummy, yaitu 1 untuk auditor Big 4 dan 0 untuk auditor non-Big 4. Auditor Big 4 memiliki kualitas audit yang lebih baik dibandingkan dengan non-Big 4. Kantor audit Indonesia yang berafiliasi dengan Big 4 adalah: Tanudiredja, Wibisana dan Rekan (PWC), Purwantono, Suherman dan Surja (EY), Osman Bing Satrio dan Rekan (Deloitte) dan Siddharta Siddharta dan Widjaja (KPMG).

\section{Variabel kontrol}

Variabel berikut dimasukkan sebagai variabel kontrol karena sesuai dengan penelitian terdahulu, variabel tersebut mempengaruhi pemilihan auditor oleh perusahaan. Variabel kontrol yang digunakan dalam penelitian ini yaitu:

(a) Pertumbuhan penjualan (GROWTH) yang diukur dengan: (penjualan $\mathrm{n}_{\mathrm{t}}$

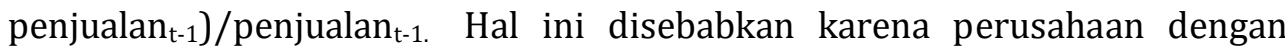
pertumbuhan yang tinggi akan cenderung memilih auditor Big 4 (Guedhami et al., 2014; Habib et al., 2017a), (b) Ukuran perusahaan (SIZE) yang diukur dengan In total asset perusahaan i. Perusahaan dengan ukuran yang lebih besar akan cenderung memilih auditor Big 4 (Guedhami et al., 2014; Habib et al., 2017a), (c) Rasio leverage (LEV) yang diukur dengan total hutang/total aset. Perusahaan dengan leverage yang lebih kecil cenderung memilih auditor big 4 (Guedhami et al., 2014; Habib et al., 2017a) dan (5) rasio persediaan (INV) yang diukur dengan persediaan dibagi total aset. Perusahaan yang memiliki rasio persediaan yang lebih cenderung memilih auditor Big 4 (Guedhami et al., 2014; Habib et al., 2017a).

\section{Pengujian Hipotesis}

Pengujian hipotesis dilakukan dengan regresi logit dengan persamaan sebagai berikut: 
$\operatorname{logit}\left(\frac{\text { Big } 4}{\text { non Big4 }}\right)=\beta_{0}+\beta_{1} \mathrm{PC}+\beta_{2}$ Growth $+\beta_{3}$ Size $+\beta_{4} \operatorname{Lev}+\beta_{5} \operatorname{Inv}+\epsilon$

Keterangan:

Big $4 \quad$ : Auditor Big 4

Non-Big 4 : Auditor non-Big 4

PC : Koneksi politik

Growth : Pertumbuhan penjualan

Size : Ukuran perusahaan

Lev : Rasio leverage

Inv : Rasio persediaan

Hipotesis diterima apabila koefisien $\beta 1$ signifikan negatif.

\section{Hasil dan Pembahasan}

\section{Hasil}

Statistik deskriptif dapat dilihat pada Tabel 1. Pada variabel audit nilai mean adalah 0,3673594 dan nilai maksimal 1 , nilai minimal 0 . Kemudian variabel koneksi politik nilai mean 0,0528529, nilai maksimal 0,75 dan nilai minimal 0 . Sedangkan variabel growth nilai mean 0,4629424, nilai maksimal 476,9463 dan nilai minimal $-2,960668$. Lebih lanjut variabel size nilai mean 21,371, nilai maksimal 26,27574 dan nilai minimal 12,49687. Untuk variabel lev nilai mean 0,2973843 , nilai maksimal 9,037284 dan nilai minimal 0,496142. Lalu untuk variabel inv nilai mean 0,1482633 , nilai maksimal 3,428499 dan nilai minimal 0,1757952 .

\section{Tabel 1. Statistik deskriptif}

\begin{tabular}{lcccc}
\hline \multicolumn{1}{c}{ Variable } & Mean & Std. Dev. & Min & Max \\
\hline Audit & 0.3673594 & 0.482233 & 0 & 1 \\
PC & 0.0528529 & 0.1029408 & 0 & 0.75 \\
Growth & 0.4629424 & 11.34319 & -2.960668 & 476.9463 \\
Size & 21.371 & 1.727394 & 12.49687 & 26.27574 \\
Lev & 0.2973843 & 0.496142 & 0 & 9.037284 \\
Inv & 0.1482633 & 0.1757952 & 0 & 3.428499 \\
\hline
\end{tabular}

AUDIT: pilihan auditor Big 4 dan non-Big 4, PC: koneksi politik, GROWTH: pertumbuhan penjualan, SIZE: ukuran perusahaan, LEV: rasio leverage, INV: rasio persediaan

Korelasi antar variabel dapat dilihat pada Tabel 2 . Korelasi pada alfa $5 \%$ terjadi pada variabel Big 4 dan koneksi politik (PC), Big 4 dan size, koneksi politik (PC) dan size, size dan inv. 
Tabel 2. Korelasi antar variabel

\begin{tabular}{ccccccc}
\hline & Big 4 & PC & Growth & Size & Lev & Inv \\
\hline Big 4 & 1 & & & & & \\
PC & $0.0777^{*}$ & 1 & & & & \\
Growth & -0.0225 & -0.027 & 1 & & & \\
Size & $0.3983^{*}$ & $0.2451^{*}$ & 0.0127 & 1 & & \\
Lev & -0.0037 & 0.0355 & -0.006 & -0.0403 & 1 & 1 \\
Inv & -0.0314 & -0.1217 & -0.0187 & $-0.0847^{*}$ & -0.0372 & 1 \\
\hline
\end{tabular}

Hasil pengujian hipotesis satu dapat dilihat pada Tabel 3. Tabel ini menunjukkan bahwa jumlah observasi sebanyak 1.230. Pseudo $R 2$ adalah sebesar 0,1734 yang bisa diartikan bahwa variasi pemilihan auditor Big 4 sebesar 17,34\% bisa dijelaskan oleh koneksi politik, pertumbuhan (growth), ukuran perusahaan (size), leverage (lev) dan rasio persediaan (inv). Prob $>$ chi2 bernilai 0,0000 berada di bawah alfa $5 \%$ menunjukkan bahwa model fit, bahwa variabel koneksi politik, growth, size, lev dan inv bisa menjelaskan pemilihan auditor Big 4.

Tabel 3. Hasil pengujian hipotesis

\begin{tabular}{|c|c|c|c|}
\hline Variables & $\begin{array}{l}\text { (Coef) } \\
\text { Audit }\end{array}$ & $\begin{array}{l}\text { (Odds Ratio) } \\
\text { Audit }\end{array}$ & $\begin{array}{c}\text { Hasil Keputusan } \\
\text { Hipotesis }\end{array}$ \\
\hline $\mathrm{PC}$ & $\begin{array}{c}-1.311^{* *} \\
(0.652)\end{array}$ & $\begin{array}{c}0.269^{* *} \\
(0.1757)\end{array}$ & Didukung \\
\hline Size & $\begin{array}{l}0.754^{* * *} \\
(0.0542)\end{array}$ & $\begin{array}{l}2.125^{* * *} \\
(0.115)\end{array}$ & Didukung \\
\hline Growth & $\begin{array}{l}-0.205 \\
(0.131)\end{array}$ & $\begin{array}{c}0.815 \\
(0.106)\end{array}$ & Tidak didukung \\
\hline Lev & $\begin{array}{l}-1.130^{* * *} \\
(0.321)\end{array}$ & $\begin{array}{l}0.323^{* * *} \\
(0.104)\end{array}$ & Didukung \\
\hline Inv & $\begin{array}{c}0.411 \\
(0.458)\end{array}$ & $\begin{array}{c}1.509 \\
(0.691)\end{array}$ & Tidak didukung \\
\hline Constant & $\begin{array}{c}-16.55^{* * *} \\
(1.175)\end{array}$ & $\begin{array}{l}0.000^{* * *} \\
(0.000)\end{array}$ & \\
\hline Observations & 1,230 & 1,230 & \\
\hline LR chi2 (5) & 285.68 & & \\
\hline Prob > chi 2 & 0.0000 & & \\
\hline Pseudo R2 & 0.1734 & & \\
\hline
\end{tabular}

Standard errors in parentheses

*** $\mathrm{p}<0.01,{ }^{* *} \mathrm{p}<0.05, * \mathrm{p}<0.1$

Hasil pengujian pada Tabel 3 tampak bahwa variabel koneksi politik signifikan dalam alfa 5\% dengan arah negatif. Hasil tersebut dapat diinterpretasikan bahwa apabila koneksi politik semakin tinggi maka peluang untuk memilih 
auditor Big 4 akan turun. Besaran peluang dapat dilihat dari odds ratio. Hasil dalam Tabel 3 dapat juga diinterpretasikan bahwa setiap kenaikan 1\% koneksi politik. Oleh karenanya, peluang perusahaan untuk memilih auditor Big 4 akan turun sebesar 73,1\%. Hasil pengujian sesuai mendukung hipotesis. Variabel growth dan inv tidak signifikan, yang berarti bahwa pertumbuhan (growth) dan rasio persediaan (inv) tidak mempengaruhi peluang perusahaan memilih auditor Big 4.

Variabel size menunjukkan koefisien yang signifikan dengan arah positif, yang berarti bahwa setiap kenaikan satu satuan aset akan meningkatkan peluang memilih auditor Big 4 sebesar $112 \%$. Hal ini sesuai prediksi bahwa semakin tinggi aset perusahaan akan cenderung memilih auditor Big 4. Variabel leverage (lev) menunjukkan koefisien yang signifikan dengan arah negatif yang dapat diartikan bahwa setiap kenaikan satu satuan leverage akan mengurangi peluang untuk memilih auditor Big 4 sebesar 67,7\%. Hal ini sesuai dengan prediksi bahwa perusahaan dengan leverage yang tinggi cenderung memilih auditor non-Big 4.

\section{Pembahasan}

Hasil pengujian menunjukkan bahwa perusahaan dengan koneksi politik lebih cenderung memilih auditor non-Big 4. Hal ini dilakukan karena perusahaan ingin menutupi perilaku rent-seeking dan tunneling dari sorotan pihak luar perusahaan. Auditor non-Big 4 cenderung lebih longgar dalam pengawasan sehingga perilaku rent-seeking dan tunneling bisa jadi kurang terdeteksi oleh auditor. Perusahaan dengan koneksi politik juga cenderung untuk tidak meningkatkan transparansi, karena pemegang saham pengendali dan aliansi politiknya tetap bisa memegang kekuasaan di dalam perusahaan. Selain itu biaya untuk mempekerjakan auditor Big 4 lebih mahal dibandingkan dengan auditor non-Big 4.

\section{Simpulan}

Penelitian ini menguji perusahaan dengan koneksi politik terhadap pemilihan auditor. Hasil pengujian menunjukkan bahwa perusahaan dengan koneksi politik cenderung untuk memilih auditor non-Big 4 karena perusahaan dengan koneksi politik cenderung untuk menutupi perilaku rent-seeking dan tunneling dari sorotan pihak di luar perusahaan. Auditor non-Big 4 cenderung longgar dalam pengawasan sehingga kurang mendeteksi adanya perilaku rent-seeking dan tunneling yang dilakukan oleh perusahaan. Penelitian mendatang bisa menambahkan pengujian rent-seeking atau tunneling atau manajemen laba untuk semakin memperkuat sebab perusahaan dengan koneksi politik cenderung memilih auditor non-Big 4. 


\section{Daftar Pustaka}

Boubakri, N., Guedhami, O., Mishra, D., \& Saffar, W. (2012). Political connections and the cost of equity capital. Journal of Corporate Finance, 18(3), 541-559. https://doi.org/10.1016/j.jcorpfin.2012.02.005

Chaney, P. K., Faccio, M., \& Parsley, D. (2011). The quality of accounting information in politically connected firms. Journal of Accounting and Economics, 51(1-2), 5876. https://doi.org/10.1016/j.jacceco.2010.07.003

Claessens, S., Djankov, S., Fan, J. P. H., \& Lang, L. H. P. (2002). Disentangling the Incentive and Entrenchment Effects of Large Shareholdings. The Journal of Finance, 57(6), 2741-2771.

DeAngelo, L. E. (1981). Auditor size and audit fees. Journal of Accounting and Economics, 3(May), 183-199.

Dinc, I. S. (2005). Politicians and banks : Political influences on government-owned banks in emerging markets. Journal of Financial Economics, 77, 453-479. https://doi.org/10.1016/j.jfineco.2004.06.011

Faccio, M. (2006). Politically Connected Firms. The American Economic Review, 96(1), 369-386. https://doi.org/10.1257/000282806776157704

Fan, J. P. H., \& Wong, T. J. (2005). Do external auditors perform a corporate governance role in emerging markets? Evidence from East Asia. Journal of Accounting Research, 43(1), 35-72. https://doi.org/10.1111/j.1475-679x.2004.00162.x

Fukuoka, Y. (2013). Indonesia's "democratic transition" revisited: A clientelist model of political transition. Democratization, 20(6), 991-1013. https://doi.org/10.1080/13510347.2012.669894

Guedhami, O., Pittman, J. A., \& Saffar, W. (2014). Auditor choice in politically connected firms. Journal of Accounting Research, 52(1), 107-162. https://doi.org/10.1111/1475-679X.12032

Habib, A., Muhammadi, A. H., \& Jiang, H. (2017a). Political connections, related party transactions, and auditor choice: Evidence from Indonesia. Journal of Contemporary Accounting and Economics, 13(1), 1-19. https://doi.org/10.1016/j.jcae.2017.01.004

Habib, A., Muhammadi, A. H., \& Jiang, H. (2017b). Political Connections and Related Party Transactions: Evidence from Indonesia. International Journal of Accounting, 52(1), 45-63. https://doi.org/10.1016/j.intacc.2017.01.004

Haw, I.-M., Hu, B., Hwang, L.-S., \& Wu, W. (2004). Ultimate Ownership, Income Management, and Legal and Extra-Legal Institutions. Journal of Accounting Research, 42(2), 423-462.

Klapper, L. F., \& Love, I. (2004). Corporate governance, investor protection , and performance in emerging markets. Journal of Corporate Finance, 10, 703-728. https://doi.org/10.1016/S0929-1199(03)00046-4

Wu, W., Wu, C., Zhou, C., \& Wu, J. (2012). Political connections, tax benefits and firm performance: Evidence from China. Journal of Accounting and Public Policy, 31(3), 277-300. https://doi.org/10.1016/j.jaccpubpol.2011.10.005 